\title{
A study of pulmonary dust deposits using the electron microscope in conjunction with the electron sound analyser
}

\author{
R. PAR IENTE, J.P. B ER R Y, P. G A L LE, E. CA Y R O L, \\ and G. BROUET \\ Hôpital Laennec, Paris
}

Castaing's electronic microsound method has been used to locate mineral particles in lung tissue. Silicon and other minerals were found in the interstitial elastic-type fibres in the lungs of patients with pulmonary fibrosis.

Considerable amounts of mineral particles are normally found in all adult lungs. Scanning with an electron microprobe microanalyser reveals many such particles in test swabs taken from all lungs. Analysis of the mineral elements present, however, gives no information as to how or where the mineral deposits are laid down within the lung. In this investigation an attempt was made first to analyse the nature of the dusts present and then, by the use of electron microscopy, to try to determine where they were deposited in the lung structure. Electron microprobe analysis has been described by Galle (1970) and it has now been applied successfully to a number of biological tissues including the lung (Berry, Pariente, and Watchi, 1969).

\section{MATERIAL AND METHODS}

The structure of two groups of lung lesions was studied by electron miscroscopy. The first group comprised samples of lung scars taken from patients dying from non-pulmonary diseases, and the second group samples of lung taken from six patients suffering from idiopathic diffuse interstitial pulmonary fibrosis (fibrosing alveolitis). In the second group, the specimens were obtained by surgical biopsy, needle aspiration biopsy or necropsy.

The tissues were fixed for electron microscopical examination by the double fixation process-one hour in $2.7 \%$ glutaraldehyde in cacodylate buffer followed by one hour in osmium tetroxide.

Dehydration followed directly after fixation, the block being immersed in $70 \%$ alcohol for 15 minutes to 2 hours, then in $80 \%$ alcohol for 10 minutes, and lastly in absolute alcohol for one hour. The blocks were immersed first in propylene oxide, then in a mixture consisting of equal amounts of propylene oxide and Epon (one hour), and finally they were embedded in Epon.
Oxidization was achieved by floating ultra-thin sections, using the rings described by Marinozzi (1964), in $10 \%$ periodic acid solution for 20 minutes.

Enzymatic digestion of elastic tissue was performed by floating the ultra-thin sections in rings according to the Bernhart technique (Monnerow and Bernhart, 1966) in the following solution:

Elastase (Beeton Dickinson 15.5 units $/ \mathrm{mg}$ in saccharose).

$1 \mathrm{mg} / \mathrm{ml}$ solution in tris $+\mathrm{HCl}$ buffer at $\mathrm{pH} 7.4$ during 30 minutes at $37^{\circ} \mathrm{C}$.

Control sections were treated at the same $\mathrm{pH}$ and temperature.

After being washed a number of times, the sections were collected on a grid and stained with uranyl acetate followed by lead citrate (10 minutes). The sections were then examined under an Elmiskop 101 Siemens electron microscope at $80 \mathrm{kV}$.

As the apparatus used serves both as an electron microscope and as a microsound, it was possible to analyse ultra-thin sections. The thickness of the sections ranged from 500 to 1,500 Ängstroms, but in order to prevent the preparations from becoming too hot it was found preferable to face them with a very fine metallic layer, 100 Ängstroms thick. The examination was performed with Castaing's 11 SE Cameca as modified by Galle (1970).

Analysis of the elements present in the lung samples was made by the microanalyser which uses an electronic sound. A small part of the section is scanned by a fine beam of electrons which strike an area of about 1 square micron of the section. This portion of tissue behaves as an anticathode and gives rise to secondary $X$ rays of characteristic wavelength. The wavelengths of the emitted $X$ rays are measured and from these the nature of the elements in the tissue is deduced, provided that the atomic numbers of the elements present are greater than 5 .

\section{RESULTS}

In both groups, the electron analyser revealed large amounts of silicon together with other mineral sub- 


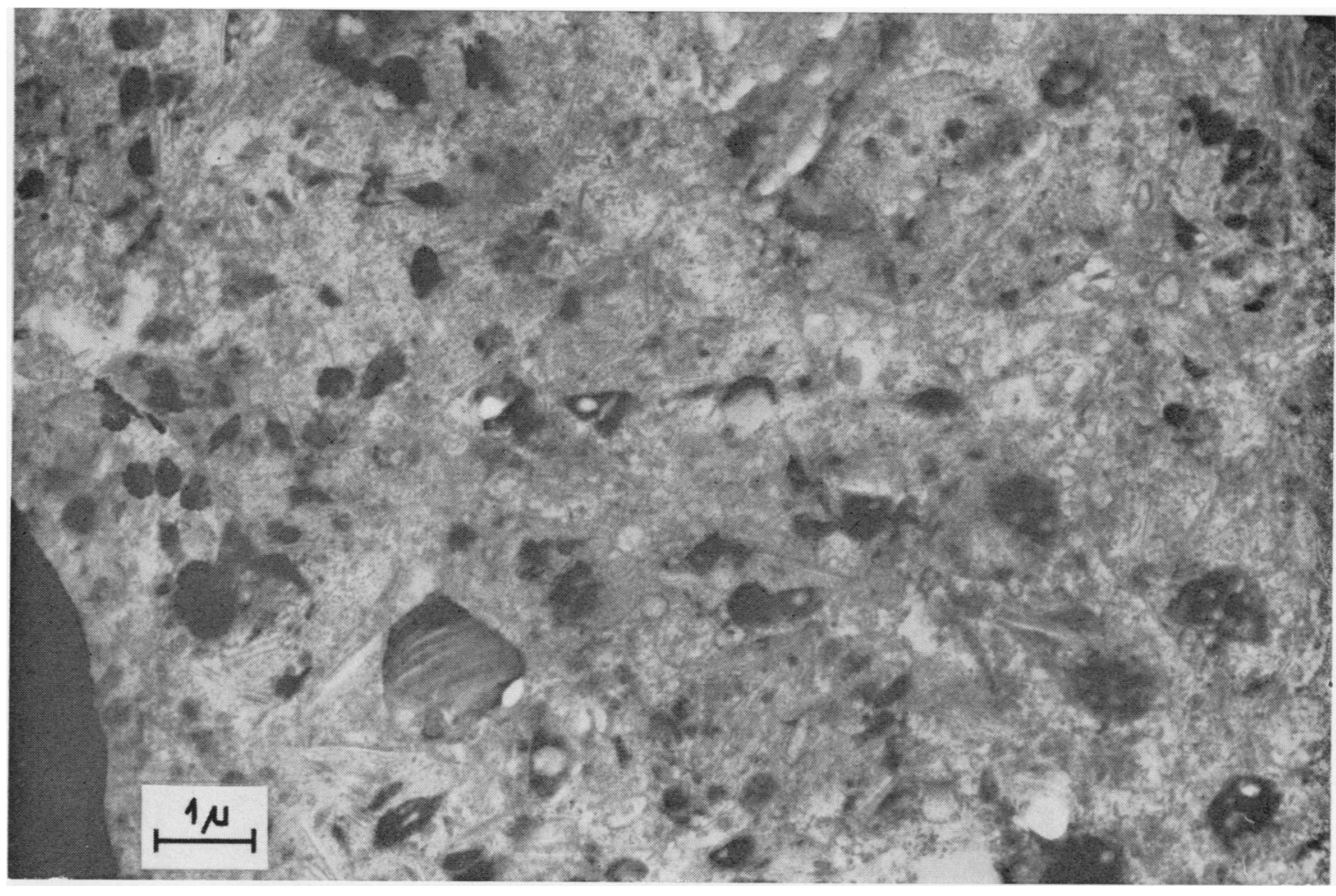

FIG. 1. A lung macrophage containing silica.

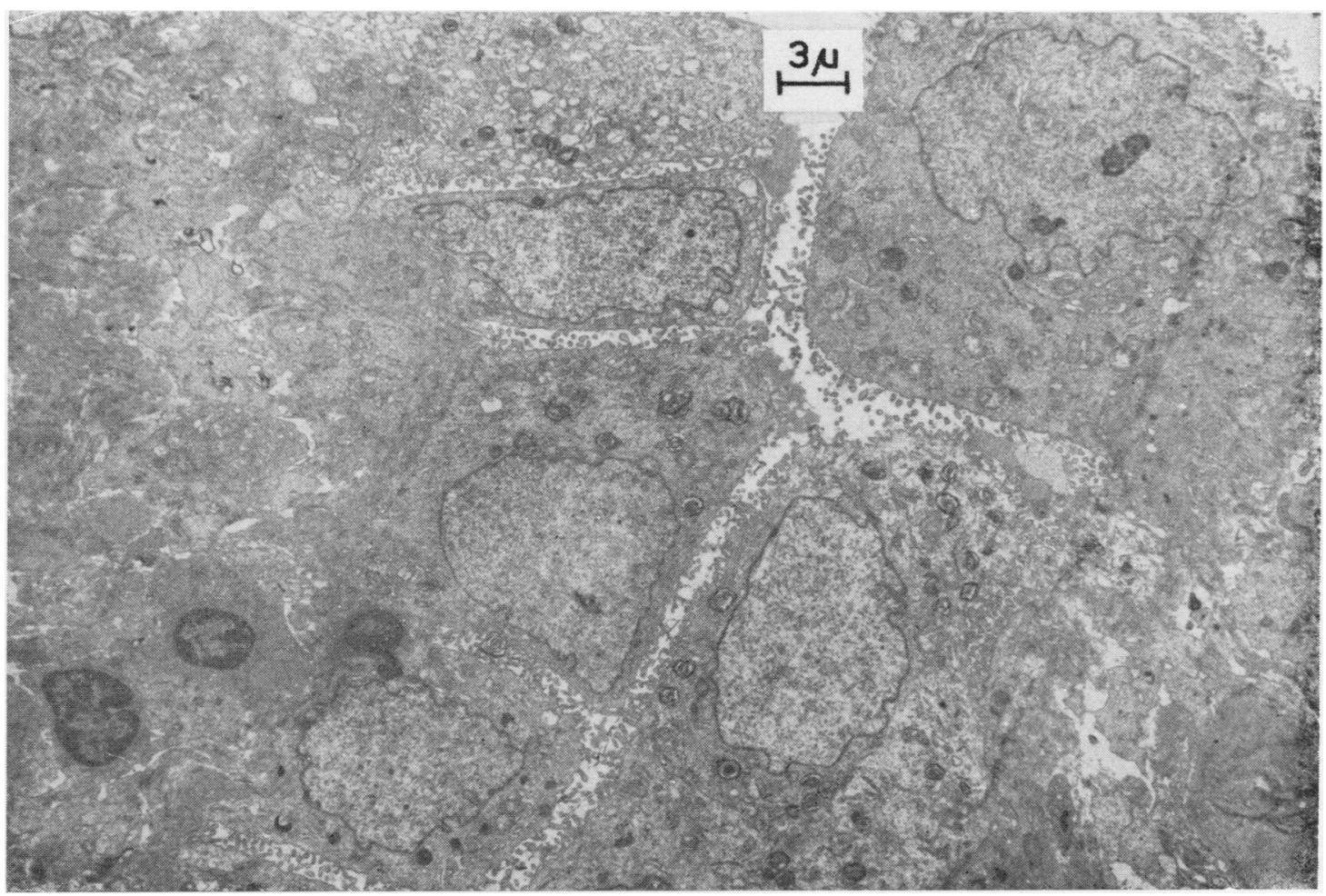

FIG. 2. Hyperplasia of type 2 pneumocytes in pulmonary interstitial fibrosis. 


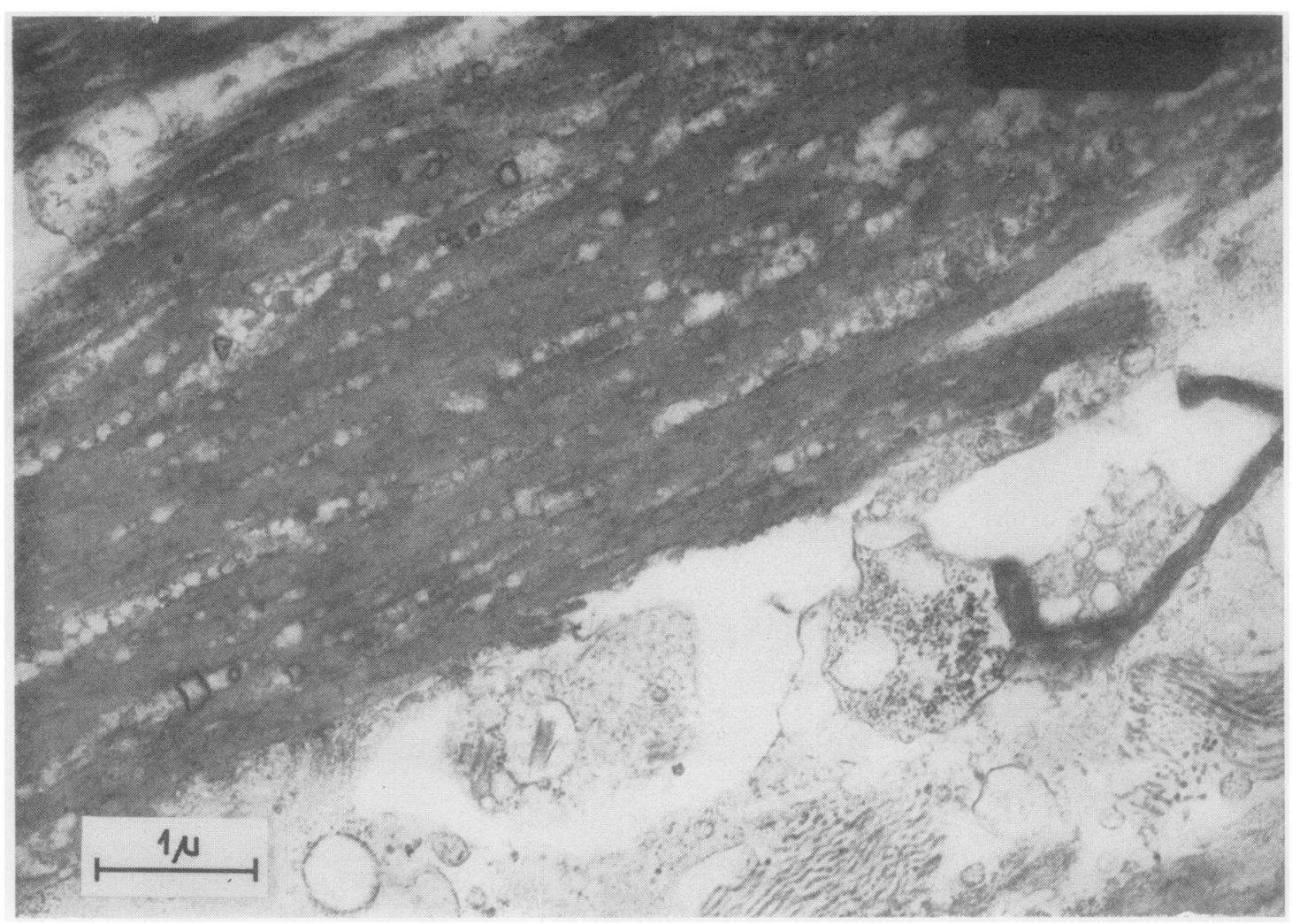

FIG. 3. Interstitiai tissue from a case of interstitial fibrosis of the lung showing large amounts of elastic tissue in which large quantities of silicon were identified.

stances formed of different elements situated within elastic-type fibres. Elastase digestion caused lysis of these osmiophilic fibres and the consequent disappearance of the mineral deposits.

The mineral deposits, however, were also found to be present within macrophage cells contained in the alveolar spaces and in the interstitial tissues (Fig. 1) as well as within the elastic-type fibres found in the interstitium. The elements identified included silicon, aluminium, iron, and magnesium but not calcium.

In both groups of lungs it was found that in the alveoli type 2 pneumocytes had replaced the normal predominant type 1 lining cells to a greater or lesser extent (Fig. 2), and in addition there were numerous electron opaque fibres, thought to be modified elastic fibres showing non-periodic striation, in the interstitial tissue (Fig. 3). These elastic-like fibres were osmiophilic.

From this investigation it appeared that silica and mineral deposits, other than calcium, are partly laid down in the interstitial elastic-type fibres and that this type of fibre is increased in amount in cases where there is interstitial alveolar fibrosis. It was also considered possible that the increased mineral content found in the elastic type of fibres might play a part in the pathogenesis of the gross lung lesions.

\section{REFERENCES}

Berry, J. P., Pariente, R., and Watchi, J. M. (1969). Analyse au microanalyseur à sonde électronique du pigment noir pulmonaire. Rev. franç. Étud. clin. biol., 14, 915.

Galle, P. (1970). L'analyse par microsonde électronique. nouvelle méthode d'exploration cellulaire. Information Médical Mensuel EX. No. spécial annuel 1, p. 653.

Marinozzi, A. (1964). Cytochimie ultra-structurale du nucléole RNA et protéines intra-nucléolaires. J. Ultrastruct. Res., 10, 433.

Monnerow, A. and Bernhart, W. (1966). Action de certaines enzymes sur destissus inclus en Epon. J. Micr., 566, 697. 